\title{
Intensive study of freshwater red algae (Rhodophyta) in Finland
}

\author{
Pertti Eloranta ${ }^{1}$, Anssi Eloranta $^{2} \&$ Pasi PerämÄKI ${ }^{2}$
}

\author{
1 Sinkilätie 13, FI 40530 Jyväskylä, Finland; Corresponding author e-mail: pertti.eloranta@elisanet.fi \\ 2 Centre for Economic Development, Transport and the Environment of Central Finland, PL 250, Jyväskylä, \\ Finland
}

\begin{abstract}
Freshwater red algae (Rhodophyta) were studied in Central Finland by examining 2224 rivers and brooks during the open water periods of the years 2012-2015 with supplementary sampling in S- and SWFinland, the W-coast rivers and Lapland. A total of 1957 records of algae were made. Approximately 56.2\% of the studied locations had 1-6 taxa. The total taxa collected were 25, with 5 taxa new to Finland. While sampling, ecological variables were recorded and measured. The most common taxa were Batrachospermum gelatinosum (37.0\%), Sheathia arcuata (10.7\%), Audouinella hermannii (11.2\%) and Sirodotia suecica (7.0\%). Lemanea spp. (9.9\%) occurred in larger rivers. Most records were from July and August, but some also in winter months. From the most rare taxa, Lemanea condensata was found in Lapland rivers, Batrachospermum vogesiacum in acid, dystrophic rivers in Central Finland, B. atrum in 7 eutrophic rivers, Kumanoa globospora in 6 rivers of Central Finland, Batrachospermum elegans in 6 and K. virgatodecaisneana in 5 harder-water rivers of SW-Finland.
\end{abstract}

Key words: Batrachospermum, ecology, Finland, freshwaters, Kumanoa, Rhodophyta, stream

\section{INTRODUCTION}

The interest in freshwater red algae has increased, especially in Europe during the last two decades. Reasons for this renewed interest are new keys (e.g. John et al. 2002, 2011; Kumano 2002; Eloranta \& KWANDRANS 2007; Eloranta et al. 2011; NeCCHI JR. \& VIs 2012; KNAPPE \& Huth 2014) and the development of new molecular methods to study phylogeny and taxonomy of taxa previously based on morphological features. Several taxa have been included to the lists of threatened algae due to rarity of rhodophytes in many European countries (Kusel-FetzMAnN 1986; KNAPPE et al. 1996; SiEMINSKa 2006).

ISRAELSON (1942) published a comprehensive work of freshwater rhodophytes in Sweden with over 2400 records of 28 taxa, which indicated that freshwater red algae are common in the North Europe. However, the floristic notes of the freshwater red algae in Finnish waters were very scarce before 1950s. Batrachospermum turfosum (as B. vagum or B. keratophytum) was mentioned as common taxon in softwater, acid forest lakes (Grönblad 1934; Cedercreutz 1944; Häyren 1945). Audouinella chalybea (as Chantransia chalybea) was noted by HäYRen (1945). Lemanea sp. was recorded from NE-Lapland by CEDERCREUTZ (1929), an area currently Russian territory. SkUנA (1933) ex- amined samples previously collected from 1861-1932 in Botanical Museum of the University of Helsinki. He identified from those samples 16 taxa, from three genera, Batrachospermum (11), Lemanea (3) and Sirodotia (2). Between 1950 to 1990 no new records were published of freshwater red algae in Finland, except one record of Hildenbrandia rivularis from SW-Finland (LUTHER 1954). The first author collected in the late 1980s, diatom and macroalgal samples from 60 river locations in Central Finland. Those samples were analysed by dr hab. Janina Kwandrans in 1991 and red algae occurred in 39 locations (65\%), with one location having six taxa present. In total, 13 taxa were identified from that material (ELORANTA \& KWANDRANS 1996). Tuomeya americana (Kütz.) PAPENfuss occurred in two locations, which provided the impetus to start more intensive studies of red algae in Finnish waters (KwANDRANS \& ELORANTA 1994).

Many records of freshwater red algae are floristic without ecological information. ISRAELSON (1942) provided some notes about the autecology of rhodophytes in Sweden. Sheath \& Hambrook (1990) did the most comprehensive work and review concerning ecology and biology of rhodophytes, mostly based on data from North America, NeCCHI JR. (1990) and NECCHI JR. et al. (2000) provided information from Brazil. Pipp \& Rotт (1993) and RotT et al. (1999) listed some 
red algae in relation to trophy and saprobity in Austrian waters.

The aim of this study was to study the commonness of rhodophytes in Finnish inland waters, their ecology and suitability for river quality evaluation and monitoring.

\section{Methods}

The intensive sampling started in late summer 2012 with the preliminary sampling in one restricted drainage basin (14.448 Leukunjoki river basin, $101.48 \mathrm{~km}^{2}$ ) in the northwestern part of the province Central Finland. During this sampling, 217 locations were studied and 317 samples were collected. Sampling continued throughout the province during open water periods in 2013 and 2014 by three trained teams, who checked 1763 locations with positive records in $47.7 \%$ (Fig. 1).

The most intensive study was conducted in the province of Central Finland, but supplementary sampling was done in August 2014 and 2015 in S-, SW- and W-parts of Finland, and Lapland to broaden the ecological information available for taxa. Self-made viewer fitted with diver's led-pulp lamp and large pipette (ø $30 \mathrm{~mm}$, length $30 \mathrm{~cm}$ ) was used in sampling and samples were preserved in $2.5 \%$ glutaraldehyde.

Part of some specimens was dried in silica desiccant for DNA extraction and molecular analyses were done in Ohio University, U.S.A. under supervision of prof. Morgan Vis. These analyses were part of large Polish project "Diversity of Freshwater Rhodophyta of chosen water ecosystems in Poland with molecular studies of relationships within some European populations" (KwANDRANS 2014).

In the field, several habitat variables were measured (multimeter WTW Multi 3420 Set C) and recorded: water temperature, $\mathrm{pH}$, conductivity, current velocity $(0=$ standing water, $1=<0.2 \mathrm{~m} . \mathrm{s}^{-1}, 2=0.2-0.5 \mathrm{~m} . \mathrm{s}^{-1}, 3=0.5-1 \mathrm{~m} . \mathrm{s}^{-1}$ and $\left.4=>1 \mathrm{~m} \cdot \mathrm{s}^{-1}\right)$, water colour $(0=$ clear, $1=$ brownish, 2 = brown, $3=$ dark brown) and turbidity (value classes $0-2$ : $0=$ clear, $1=$ slightly turbid, 2 = very turbid $)$, bottom quality characteristics, channel width $(0=<1 \mathrm{~m}, 1=1-3 \mathrm{~m}, 2=$ $3-10 \mathrm{~m}$ and $3=>10 \mathrm{~m}$ ), shadowness ( 4 classes: $0=$ open, $1=$ partly shadowed by river banks and shore plants, $2=$ moderate shadowness, $3=$ always in shadow from sunshine), abundance ( 3 classes: $1=$ single thallus, $2=$ several thalli in sampling area, 3 = very rich coverage by rhodophytes), substratum of rhodophytes, and abundance of water mosses (3 classes).

In the laboratory, samples were cleaned and preidentified in BMS stereomicroscope and the final identification and documentation was conducted using an Olympus BX50 microscope fitted with Nikon Digital Sight DS-U1 camera. Samples were deposited Botanical Museum, Finnish Museum of Natural History, Helsinki (HU).

\section{RESUlts}

The sampling program was primarily focused on running waters. Most of the channels with rhodophytes were $1-3 \mathrm{~m}(50.2 \%)$ or $3-10 \mathrm{~m}(32.3 \%)$ wide with current velocity $0.2-0.5$ m.s ${ }^{-1}$ (48.7\%) (Fig. 2).

Waters in Central Finland are typically soft with low conductivity and often brown and acid due to humic substances (Fig. 3).

During the study years 2012-2014, a total of 1980 riverine locations were studied with $47.7 \%$ having red algae. During supplementary sampling in August 2015, 244 additional locations were studied. A total of 2020 specimens, of 25 taxa, were collected. In locations with positive records, 1-6 taxa were identified (Fig. 4).

The majority of the places were in small forest brooks and red algae grew on stones, rocks, gravel or underwater wood (Fig. 5). Some taxa grew also on the aquatic macrophytes, vascular plants, mosses (Audouinella spp. and Sirodotia suecica) or other rhodophytes (Audouinella spp. on Lemanea spp. and Sirodotia on Batrachospermum spp.). Frequently only a single or a few thalli were found in one location, but sometimes the bottom was almost covered with rhodophytes.

During the winter months rhodophytes are in different winter stages (e.g. as overwintering thalli or in chantransia stages). E.g. Lemanea thalli were only $1-1.5 \mathrm{~cm}$ long and very thin hairs in December in cold water $\left(\approx 2^{\circ} \mathrm{C}\right)$ and with very short days and low light radiation. At the same time, Audouinella hermannii tufts were growing up on mosses and stones. The first signs of new growth for Sirodotia suecica and Batrachospermum spp. were observed in April during ice and snow melting time. Sampling in May in Finnish waters is difficult due to flooding of all rivers and brooks after snow melting. During open water period the most records were made in summer months with maximum in July (Fig. 6). Batrachospermum skujae was most often found in early summer (June). It is morphologically separated from $B$. gelatinosum in having monospores.

The most common taxa were Batrachospermum gelatinosum (37.0\%), Sheathia arcuata (10.7\%), Audouinella hermannii (11.2\%) and Sirodotia suecica (7.0\%). Lemanea spp. (9.9\%) occurred in larger rivers (Table 1, Fig. 7).

Batrachospermum tufosum is very common in Finnish forest and peatland lakes with low conductivity and often with acid water, but is underestimated (56 records; $2.9 \%$ ) in this running water study.

In addition to the identified taxa, some unidentified samples were collected, which did not fit with the recent taxonomical keys.

\section{Autecological notes}

Batrachospermum turfosum grew most often in lake littoral or in slow flowing outlets from peatland lakes and Lemanea spp. favoured fast flowing larger open rivers with high current velocity (Fig. 7). In addition, Audouinella spp. occurred often in fast flowing places, growing on water mosses (Fontinalis spp.), on Lema- 


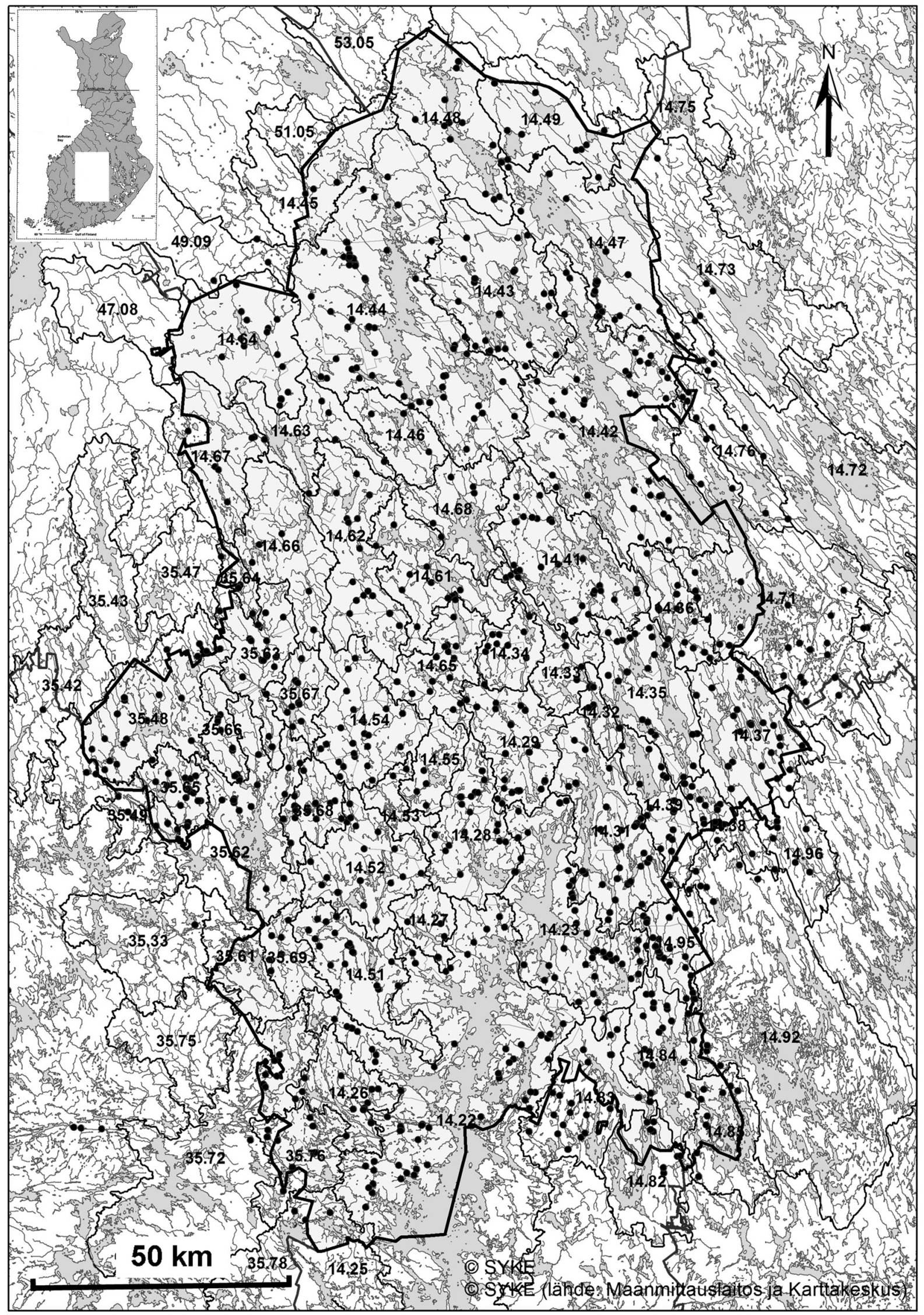

Fig. 1. Distribution of positive records in the province of Central Finland. 
Table 1. Taxa and frequencies recorded in the years 2012-2015 (a total number of records $=1957$; studied streams $\mathrm{N}=2224$ ).

\begin{tabular}{|c|c|c|c|c|c|c|}
\hline Taxon / Year & 2012 & 2013 & 2014 & 2015 & Total & $\%$ \\
\hline $\begin{array}{l}\text { Audouinella hermannii (Roth) DuBy in De } \\
\text { CANDOLLE }\end{array}$ & 31 & 80 & 54 & 55 & 220 & 11.2 \\
\hline A. chalybea (Rотн) BoRY & 4 & 28 & 26 & 30 & 58 & 4.5 \\
\hline Audouinella sp. & 0 & 8 & 8 & 0 & 16 & 0.8 \\
\hline Batrachospermum atrum (HUdSON) HARVEY & 1 & 0 & 0 & 6 & 7 & 0.4 \\
\hline B. elegans Sirodot emend SHEATH et al. & 0 & 0 & 3 & 3 & 6 & 0.3 \\
\hline $\begin{array}{l}\text { B. gelatinosum (Linnaeus) De CANDOLle emend. } \\
\text { Vis et al. }\end{array}$ & 132 & 277 & 240 & 75 & 724 & 37.0 \\
\hline B. cf. gelatinosum & 3 & 27 & 1 & 0 & 31 & 1.6 \\
\hline B. helminthosum Bory emend. SHEATH et al. & 0 & 10 & 11 & 16 & 37 & 1.9 \\
\hline B. keratophytum BORY emend. SHEATH et al. & 1 & 3 & 3 & 1 & 8 & 0.4 \\
\hline B. cf. periplocum & 0 & 0 & 1 & 0 & 1 & 0.1 \\
\hline B. skujae GeItLer emend. Vis et al. & 18 & 14 & 9 & 2 & 43 & 2.2 \\
\hline B. cf. skujae & 0 & 1 & 1 & 0 & 2 & 0.1 \\
\hline B. turfosum Bory emend. SHEATH et al. & 17 & 18 & 21 & 0 & 56 & 2.9 \\
\hline B. vogesiacum Schulz ex SkUja & 1 & 4 & 3 & 2 & 10 & 0.5 \\
\hline Batrachospermum sp. & 0 & 12 & 18 & 8 & 38 & 1.9 \\
\hline Kumanoa globospora (ISRAELSON) ENTWISLE et al. & 0 & 4 & 2 & 0 & 6 & 0.3 \\
\hline K. virgatodecaisneana (SIRODOT) ENTwISLE et al. & 0 & 0 & 4 & 1 & 5 & 0.3 \\
\hline Lemanea borealis ATKINSON & 2 & 3 & 2 & 0 & 7 & 0.4 \\
\hline L. cf. borealis & 3 & 4 & 2 & 0 & 9 & 0.5 \\
\hline L. condensata ISRAELSON & 2 & 0 & 0 & 8 & 10 & 0.5 \\
\hline L. fluviatilis (LinnaEus) C. AgardH & 11 & 17 & 22 & 28 & 78 & 4.0 \\
\hline L. cf. fluviatilis & 0 & 4 & 2 & 0 & 6 & 0.3 \\
\hline L. fucina BORY & 13 & 19 & 14 & 17 & 63 & 3.2 \\
\hline L. cf. fucina & 1 & 5 & 6 & 0 & 12 & 0.6 \\
\hline L. rigida (SIRODOT) De TONI & 1 & 2 & 2 & 0 & 5 & 0.3 \\
\hline L. cf. rigida & 1 & 0 & 2 & & 3 & 0.2 \\
\hline Lemanea sp. & 0 & 11 & 5 & & 16 & 0.8 \\
\hline Sheathia arcuata (KyLIN) SALOMAKI et M.L.VIS & 24 & 84 & 78 & 23 & 209 & 10.7 \\
\hline S. cf. arcuata & 4 & 19 & 9 & 0 & 32 & 1.6 \\
\hline S. boryana (SIRODOT) SALOMAKI et M.L.VIS & 0 & 0 & 4 & 0 & 4 & 0.2 \\
\hline S. confusa (Bory) SAlOMAKI et M.L.Vis & 3 & 7 & 20 & 3 & 33 & 1.7 \\
\hline S. ,exigua ' SALOMAKI et VIS & 1 & 15 & 10 & 0 & 26 & 1.5 \\
\hline S. cf. 'exigua' & 0 & 5 & 2 & & 7 & 0.4 \\
\hline Sirodotia suecica KYLIN & 35 & 37 & 42 & 23 & 137 & 7.0 \\
\hline Tuomeya americana (KÜTZING) PAPENFUSS & 2 & 0 & 0 & 0 & 2 & 0.1 \\
\hline
\end{tabular}


Table 2. Ecological range values (mean, minimum and maximum) for recorded taxa [channel width: (0) <1 m, (1) 1-3 m, (2) 3-10 m, (3) $>10$ $\mathrm{m}$; current velocity: (0) standing water, (1) $<0.2 \mathrm{~m} . \mathrm{s}^{-1}$, (2) $0.2-0.5 \mathrm{~m} . \mathrm{s}^{-1}$, (3) $0.5-1 \mathrm{~m} . \mathrm{s}^{-1}$ and (4) $>1 \mathrm{~m} . \mathrm{s}^{-1}$; water colour: (0) clear, (1) brownish, (2) brown, (3) dark brown; turbidity: (0) clear, (1) slightly turbid, (2) very turbid].

\begin{tabular}{|c|c|c|c|c|c|c|c|}
\hline Taxon & $\begin{array}{l}\text { Channel } \\
\text { width } \\
(0-3)\end{array}$ & $\begin{array}{c}\text { Current } \\
\text { velocity } \\
(0-4)\end{array}$ & $\begin{array}{c}\text { Water } \\
\text { colour } \\
(0-3)\end{array}$ & $\begin{array}{l}\text { Turbi- } \\
\text { dity } \\
(0-3)\end{array}$ & $\begin{array}{c}\text { Tempe- } \\
\text { rature } \\
\left({ }^{\circ} \mathrm{C}\right)\end{array}$ & $\begin{array}{l}\text { Conductivity } \\
\qquad\left(\mu \mathrm{S} . \mathrm{cm}^{-1}\right)\end{array}$ & pH \\
\hline Audouinella chalybea & 1.9 & 2.5 & 1.2 & 0.9 & 17.8 & 82 & 6.70 \\
\hline $\min$ & 0.0 & 1.5 & 0.0 & 0.0 & 10.4 & 20 & 5.8 \\
\hline $\max$ & 3.0 & 4.0 & 3.0 & 2.0 & 26.2 & 280 & 7.5 \\
\hline A. hermannii & 1.9 & 2.6 & 1.1 & 0.8 & 17.8 & 66 & 6.71 \\
\hline $\max$ & 0.0 & 1.0 & 0.0 & 0.0 & 8.2 & 21 & 4.7 \\
\hline $\min$ & 3.0 & 4.0 & 3.0 & 2.0 & 25.8 & 184 & 7.8 \\
\hline Batrachospermum atrum & 2.0 & 2.0 & 1.5 & 0.8 & 15.1 & 93 & 7.08 \\
\hline $\min$ & 1.0 & 1.0 & 0.0 & 0.0 & 13.5 & 55 & 6.2 \\
\hline $\max$ & 3.0 & 3.0 & 3.0 & 1.0 & 18.1 & 153 & 7.4 \\
\hline B. elegans & 2.1 & 2.4 & 0.8 & 0.8 & 20.9 & 76 & 6.67 \\
\hline $\min$ & 1.0 & 2.0 & 0.0 & 0.0 & 16.0 & 53 & 6.1 \\
\hline $\max$ & 3.0 & 2.5 & 2.0 & 1.0 & 23.8 & 131 & 7.1 \\
\hline B. gelatinosum & 2.5 & 2.5 & 1.5 & 1.0 & 22.2 & 66 & 6.47 \\
\hline $\min$ & 0.0 & 0.0 & 0.0 & 0.0 & 6.6 & 16 & 3.6 \\
\hline $\max$ & 3.0 & 4.0 & 3.0 & 2.0 & 26.2 & 690 & 7.8 \\
\hline B. helminthosum & 1.6 & 2.1 & 1.1 & 1.0 & 16.6 & 79 & 6.85 \\
\hline $\min$ & 1.0 & 1.0 & 0.0 & 0.0 & 7.8 & 28 & 6.0 \\
\hline $\max$ & 3.0 & 4.0 & 3.0 & 2.0 & 21.4 & 183 & 7.4 \\
\hline B. keratophytum & 1.3 & 2.0 & 1.3 & 1.0 & 17.6 & 20 & 6.30 \\
\hline $\min$ & 0.0 & 1.0 & 1.0 & 1.0 & 13.0 & 20 & 6.3 \\
\hline $\max$ & 2.5 & 3.0 & 2.0 & 1.0 & 23.0 & 20 & 6.3 \\
\hline B. skujae (B. sporulans) & 1.5 & 2.0 & 1.1 & 0.8 & 16.0 & 42 & 6.41 \\
\hline $\min$ & 0.0 & 0.0 & 0.0 & 0.0 & 8.2 & 21 & 4.7 \\
\hline $\max$ & 3.0 & 3.0 & 2.0 & 2.0 & 24.9 & 97 & 7.2 \\
\hline B. turfosum & 1.0 & 1.3 & 1.3 & 1.1 & 16.5 & 30 & 6.02 \\
\hline $\min$ & 0.0 & 0.0 & 0.0 & 0.0 & 10.2 & 17 & 4.9 \\
\hline $\max$ & 2.0 & 3.0 & 3.0 & 2.0 & 24.8 & 58 & 6.7 \\
\hline B. vogesiacum & 1.6 & 1.9 & 2.4 & 1.0 & 16.2 & 28 & 5.33 \\
\hline $\min$ & 1.0 & 1.0 & 1.0 & 1.0 & 12.3 & & \\
\hline $\max$ & 2.0 & 3.0 & 3.0 & 1.0 & 18.4 & & \\
\hline B. cf. periplocum & 3.0 & 2.5 & 1.5 & 1.5 & 17.1 & 41 & 6.20 \\
\hline Kumanoa globospora & 2.3 & 2.0 & 0.8 & 1.0 & 18.2 & 76 & 6.65 \\
\hline $\min$ & 2.0 & 1.0 & 0.0 & 1.0 & 15.3 & 36 & 6.5 \\
\hline $\max$ & 3.0 & 3.0 & 1.0 & 1.0 & 20.4 & 224 & 6.8 \\
\hline
\end{tabular}


Table 2 Cont.

\begin{tabular}{|c|c|c|c|c|c|c|c|}
\hline K. virgatodecaisneana & 2.1 & 2.1 & 1.7 & 1.3 & 18.2 & 232 & 6.95 \\
\hline $\min$ & 1.0 & 1.5 & 1.0 & 1.0 & 13.7 & 55 & 6.1 \\
\hline $\max$ & 3.0 & 2.5 & 2.0 & 1.5 & 23.8 & 690 & 7.7 \\
\hline Sheathia arcuata & 1.3 & 2.1 & 1.1 & 1.0 & 16.7 & 58 & 6.68 \\
\hline $\min$ & 0.0 & 1.0 & 0.0 & 0.0 & 6.0 & 17 & 5.4 \\
\hline $\max$ & 3.0 & 4.0 & 3.0 & 2.0 & 26.2 & 280 & 7.7 \\
\hline S. boryana & 2.1 & 2.6 & 0.8 & 0.2 & 17.2 & 89 & 6.83 \\
\hline $\min$ & 0.0 & 2.0 & 0.0 & 0.0 & 8.4 & 35 & 6.5 \\
\hline $\max$ & 3.0 & 3.0 & 1.0 & 1.0 & 21.4 & 169 & 7.3 \\
\hline S. confusa & 1.2 & 2.3 & 1.2 & 0.4 & 15.0 & 43 & 6.64 \\
\hline $\min$ & 0.0 & 2.0 & 0.0 & 0.0 & 6.1 & 24 & 5.9 \\
\hline $\max$ & 2.0 & 3.0 & 3.0 & 2.0 & 19.0 & 77 & 7.3 \\
\hline S. exigua (,anatinum`) & 1.5 & 2.2 & 1.2 & 1.0 & 18.2 & 116 & 6.52 \\
\hline $\min$ & 0.0 & 1.0 & 0.0 & 0.0 & 11.7 & 20 & 5.5 \\
\hline $\max$ & 3.0 & 2.5 & 2.0 & 1.5 & 22.7 & 381 & 7.4 \\
\hline Lemanea condensata & 1.8 & 2.3 & 1.8 & 0.9 & 13.9 & 72 & 6.90 \\
\hline $\min$ & 1.0 & 2.0 & 1.0 & 0.0 & 11.1 & 23 & 6.0 \\
\hline $\max$ & 3.0 & 4.0 & 3.0 & 1.0 & 16.8 & 184 & 7.8 \\
\hline L. fluviatilis & 2.3 & 2.7 & 1.2 & 0.9 & 19.1 & 73 & 6.82 \\
\hline $\min$ & 1.0 & 1.5 & 0.0 & 0.0 & 13.7 & 23 & 5.9 \\
\hline $\max$ & 3.0 & 4.0 & 3.0 & 2.0 & 26.2 & 598 & 7.5 \\
\hline L. fucina & 2.3 & 2.9 & 0.9 & 0.6 & 19.3 & 53 & 6.74 \\
\hline $\min$ & 1.0 & 1.0 & 0.0 & 0.0 & 13.5 & 26 & 5.9 \\
\hline $\max$ & 3.0 & 4.0 & 3.0 & 2.0 & 25.3 & 171 & 7.4 \\
\hline L. rigida & 2.7 & 2.9 & 1.0 & 1.0 & 21.9 & 55 & 7.05 \\
\hline $\min$ & 2.0 & 2.5 & 0.0 & 1.0 & 19.7 & 34 & 6.4 \\
\hline $\max$ & 3.0 & 3.0 & 2.0 & 1.0 & 24.4 & 71 & 7.7 \\
\hline Sirodotia suecica & 1.9 & 2.5 & 1.4 & 0.7 & 18.2 & 48 & 6.43 \\
\hline $\min$ & 0.0 & 1.0 & 0.0 & 0.0 & 10.2 & 18 & 5.6 \\
\hline $\max$ & 3.0 & 4.0 & 3.0 & 2.0 & 25.8 & 381 & 7.4 \\
\hline
\end{tabular}

nea thalli or on rocks.

Water colour is strongly related Finnish waters with the content of humic substances and therefore negatively correlated with water $\mathrm{pH}$ and conductivity. Thus, Batrachospermum vogesiacum is the most characteristic species in dark brown and acid waters with very low conductivity (Fig. 7). In addition, B. keratophytum and $B$. turfosum are typical for acid and soft waters, but they can be found also in acid clear waters. Among the rare taxa, Batrachospermum atrum occurred in eutrophic coastal rivers from the south coast to NW Finland with one location in SW-Finland. $B$ elegans was found in six hard-water rivers of SWFinland, B. vogesiacum in acid, dystrophic rivers in Central Finland. Kumanoa globospora occurred in six rivers of Central Finland, $K$. virgatodecaisneana in SW-Finland and Lemanea condensata in Lapland rivers (Figs 8, 9). In addition, Sheathia boryana prefers higher conductivity and thus were found in areas with mineral soils and neutral $\mathrm{pH}$. These taxa were in low frequency in the study material probably due to fact that the main project sampling was conducted in the province of Central Finland and many of these were occurred in SW- and S-Finland (Fig. 8). 


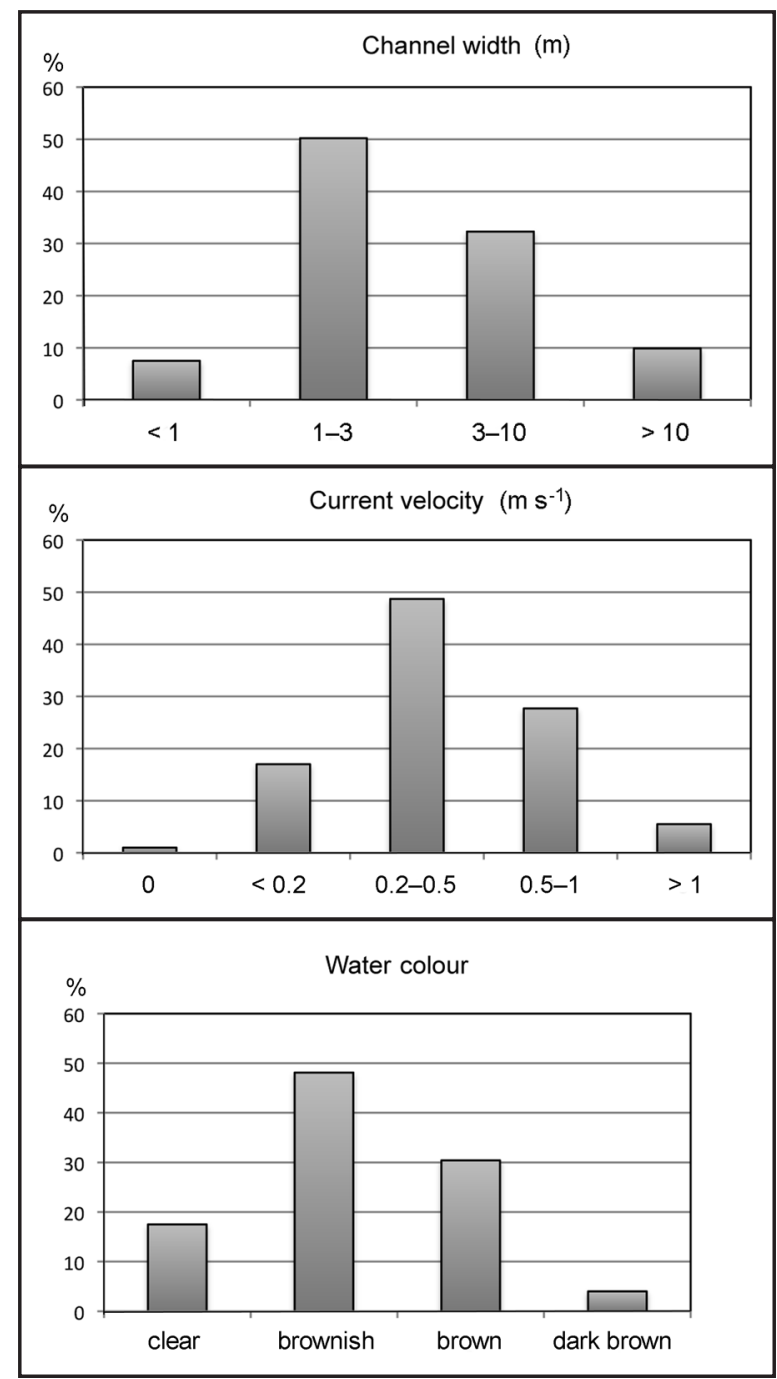

Fig. 2. Size, current velocity and colour distribution of rivers and brooks with red algae.

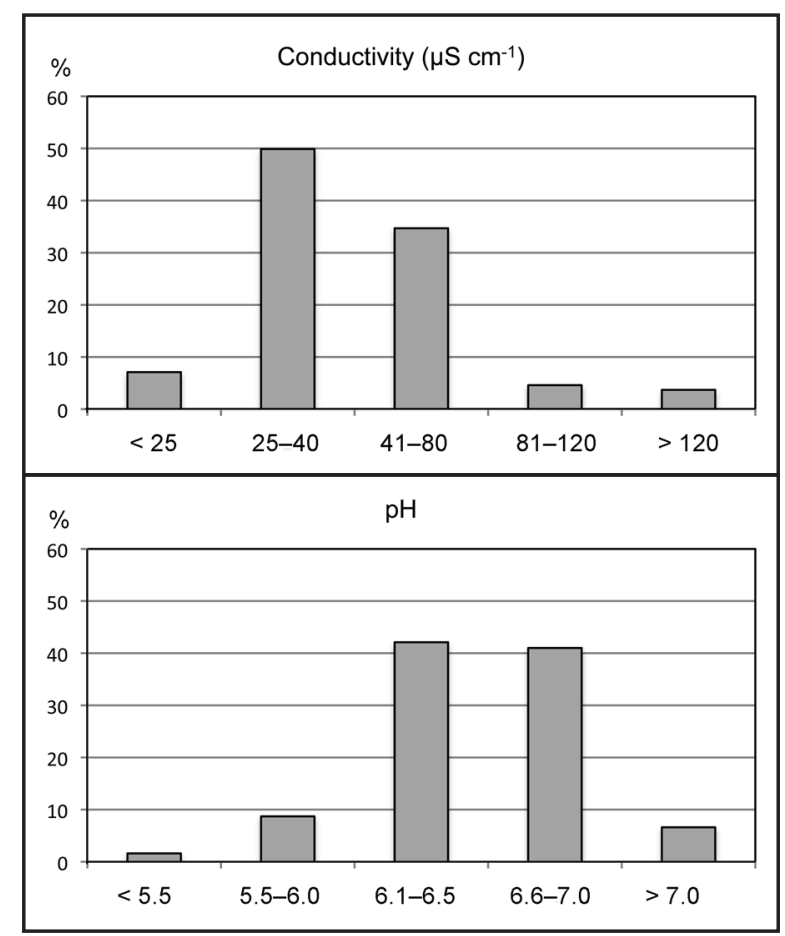

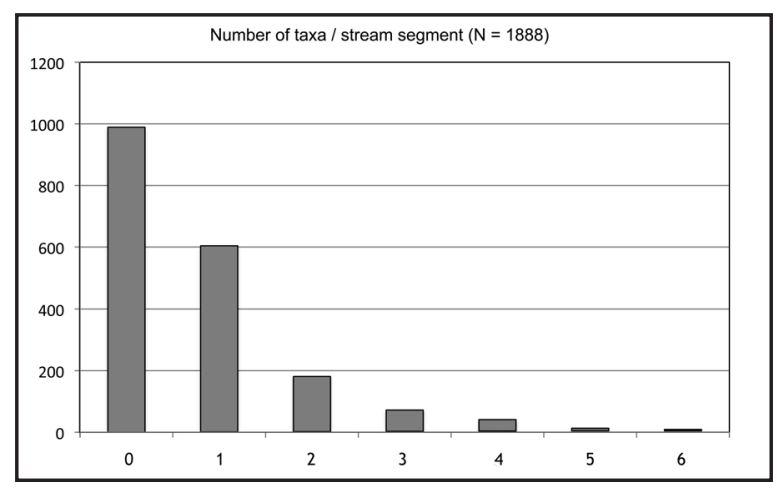

Fig. 4. Number of red algal taxa in studied Central Finnish stream segments.

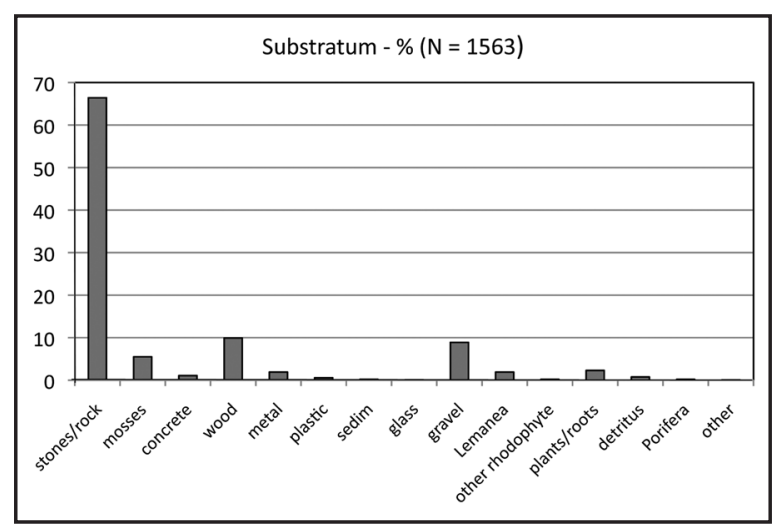

Fig. 5. Relative occurrence of red algae on different types of substrata.

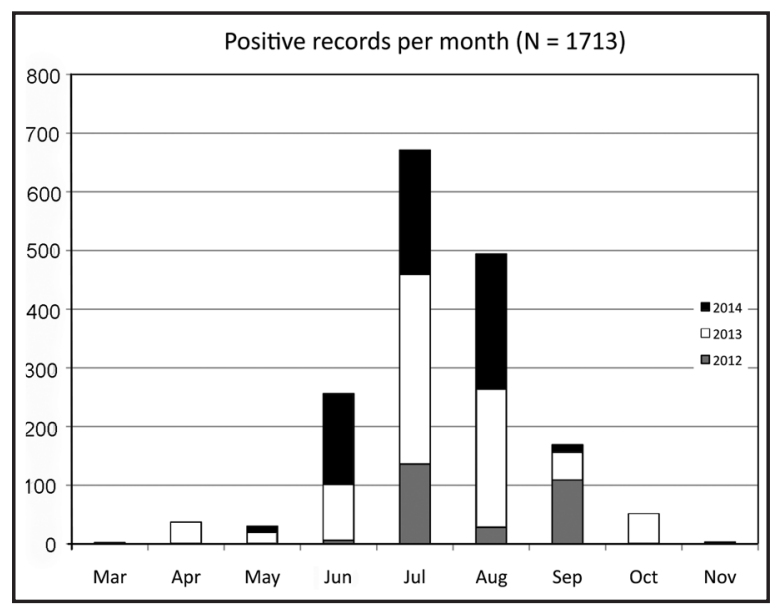

Fig. 6. Monthly records of red algae in the years 2012-2014.

Fig. 3. Conductivity and $\mathrm{pH}$ distribution of studied rivers with red algae. 


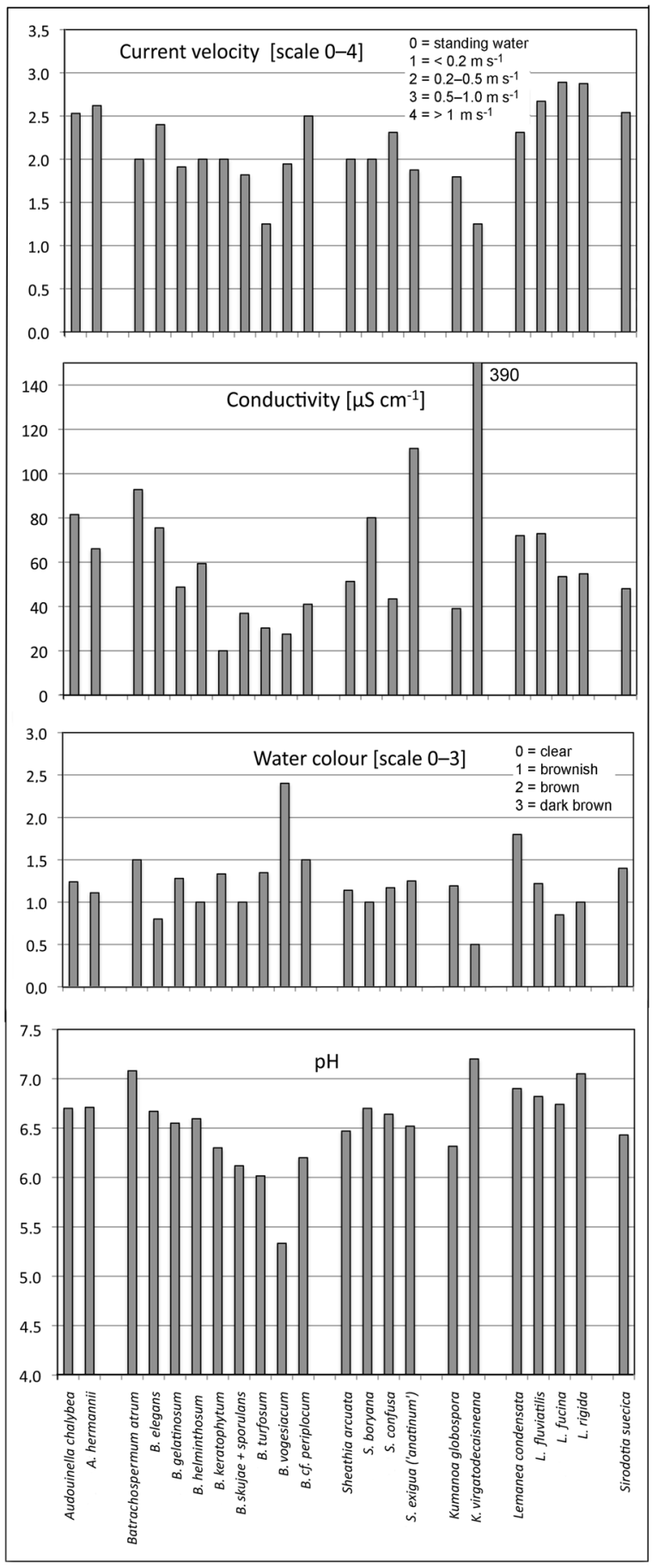

Fig. 7. Mean values of some environmental variables for different taxa.

\section{Taxonomical notes}

New red algal taxa for Finland found in this study were Lemanea condensata in ten Lapland rivers, Batrachospermum vogesiacum in acid humic rivers in Central Finland, B. elegans in six west coast rivers and Kumanoa globospora in six Central Finnish rivers. Kumanoa virgatodecaisneana was found previously in Finland 1871 from SW coast (SKuja 1933). In this study, five new records were reported in SW-Finland. One sample was identified as Batrachospermum cf. periplocum

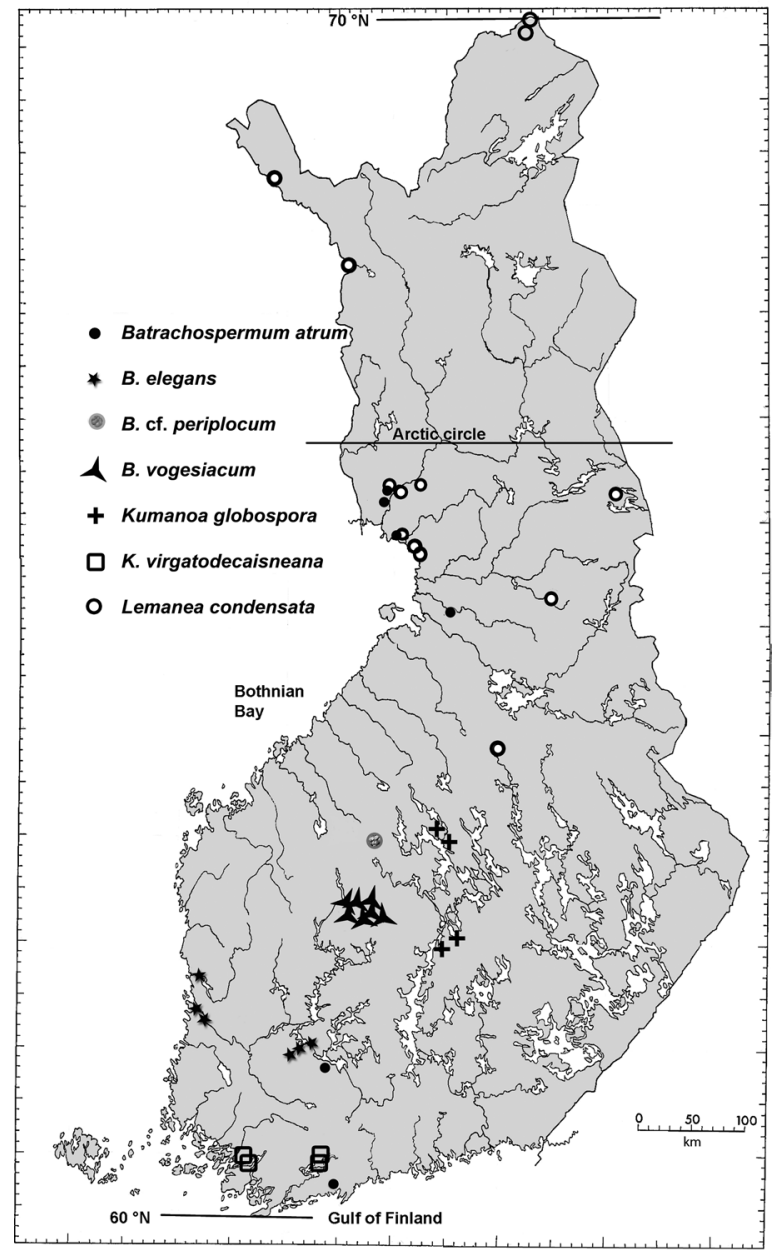

Fig. 8. Occurrence of some rare taxa in Finland.

(SKUJA) NeCCHI.

Identification of some taxa according to the morphological features is very difficult due to the wide morphological variation. Differences between dense Batrachospermum gelatinosum and Sheathia arcuata thalli are not always clear due to similar cortication type, rather similar carpogonial branch type and carposporophytes, which could be different in size and distribution in whorls. B. skujae, which has monospores as typical feature is after molecular sequencing results already synonymised with B. gelatinosum (KeIL et al. 2014). Monospores were found in this study in summer 2013 also in several Sheathia arcuata populations. In some locations grew ca. one fourth of thalli with only monospores, whereas thalli in the main part of population had only sexual reproduction organs. Monospore thalli were very different than male thalli of dioecious $S$. arcuata. During monthly monitoring of the same locations in summer 2014 any thalli with monospores were found.

One morphological feature for genus Sheathia, except $S$. arcuata, is irregular cortication with bulbous cells. However, in the Finnish material this type of irregular cortication is seen neither in $S$. boryana nor $S$. 
confusa. In S. exigua, formerly known as Batrachospermum anatinum, has chaotic cortication structure in lower parts of thallus, but not with bulbous cells.

Batrachospermum turfosum has several morphological types, which according to recent molecular studies are different species (NECCHI JR et al. 2013). Among sequenced Finnish samples were two types from three found in European material.

Sirodotia suecica varies very much depending on current conditions. In slow current, species grows often on aquatic macrophytes as very delicate form, which was previously known as own species $S$. tenuissima. In very fast current, thalli are dense almost without distinct whorls, whereas in moderate current species occurs as 'typical' form. According to the molecular analyses, all these forms are ecotypes with very similar sequence data (VIS \& SHEATH 1999; LAM et al. 2012). Typical features for Sirodotia suecica are carpogonium with hemispherical protuberance, and indefinite carposporophytes with carposporohyte filaments creeping along cortical filaments. In some Central Finnish samples, carposprophytes were rather large globular pseudo-carposporophytes and also monospores were present.

Five species of the genus Lemanea were identified. Thalli of Lemanea borealis are delicate and thin and typically with relatively long $(2 / 3)$ sterile basal part. Young thalli of L. fluviatilis are somewhat similar and without typical stalked basal part. Thus some identifications of these taxa are uncertain.

\section{Discussion}

The occurrence $(47.7 \%)$ of red algae in this study is similar with values given in literature for larger areas (North America 49\%; SHEATH \& HAMBROOK 1990; Great Britain 51\%; Holmes unpubl., in SHeATH \& HAMBroOK 1990). The group is very common also in Sweden, where the environmental conditions are similar to those in Finland (ISRAELSON1942). In the stream segments with positive records, more than one taxon occurred in $32.9 \%$ (Fig. 2). In comparison, in North America the corresponding percentage was 24\% (SHEATH \& HAMBROOK 1990).

Current velocity varies drastically in time and space in small rivers depending on season, channel width and occasionally rainstorms. Thus, the recorded values are more describing the channel character, not especially microhabitat of single taxon. Rhodophytes are in general resistant to strong current (SHEATH \& Hambrook 1990, Sheath \& Sherwood 2002) and they have been found in a wide range of current velocity (ELORANTA \& KWANDRANS 1994).

Several authors have reported that most freshwater red algae exhibit maximum biomass, growth and reproduction in the period from late fall to early summer in temperate regions (SHEATH \& HAMBrooK 1990). In the European Nordic Countries (Sweden and Finland), there is a clear decline in October and only a few taxa overwinter due to very low light radiation, freezing of streams and lakes with thick ice and snow cover (KYLIN 1912; ISRAELSON 1942). In addition, in Central Europe maximum development is found in mountain areas during the summer months (e.g. in Western Carpathian, StARMach 1984). In Central European lowlands, red algae are outcompeted by fast growing filamentous green algae like Cladophora. $\mathrm{Ba}$ trachospermum skujae was most frequently observed in early summer, similar to Sweden (KYLIN 1912; IsRAELSON 1942 for B. sporulans). Thus, B. gelatinosum reproduces in many case asexually in early summer stage with monospores and then later only sexually.

In Finnish waters, the maximum water temperature is in July (varying in the study area from 10 to $22^{\circ} \mathrm{C}$ ). Most of the samples were collected in July and the sampling activity was equal during all summer months. The abundance of red algae varied considerably in different locations and between species, but it was not recorded any clear spring/early summer and autumn maxima. However, Batrachospermum helminthosum, B. vogesiacum and Kumanoa globospora were found mostly in the second half of summer, similar to Sweden (IsRAELSON 1942). Some overwintered thalli of $B$. vogesiacum were found in early June.

Some taxa rare in Finland like Batrachospermum elegans, Kumanoa virgatodecaisneana and Sheathia boryana were collected in August from SW- and S-Finland, but those areas were studied only in August. Sheathia boryana was the most frequent taxon of the family Batrachospermaceae in a comprehensive study including Poland and the Baltic countries, where e.g. water conductivity is 10-20-fold of that in Central Finland (KWANDRANS 2014).

ISRAELSON (1942) names five biogeographical community groups according to typical freshwater red algae in Sweden: 1. Virgatum group, 2. Boryanum group, 3. Chantransia group, 4. Sirodotia group, and 5. Condensata group. Those groups are related to geographical differences in soil and bedrock qualities. The Virgatum and Boryanum groups occur in areas with higher conductivity, often with occurrence of limestone, whereas Chantransia group (with typical taxa like Audouinella spp., Lemanea fluviatilis and Batrachospermum gelatinosum) occurs in the whole Sweden. Sirodotia group (typical taxa Sirodotia suecica, Batrachospermum turfosum and Sheathia confusa) is typical in waters with low conductivity and often with humic matter. Condensata group is in Sweden mountainous with Lemanea condesata as type species. In Finland the two first groups could be found in southern and southwestern parts of country, where conductivity could be 10 - to 20-fold that in the Central Finland. Batrachospermum helminthosum (syn $B$. virgatum) occurs in Finland from the south coast to $65^{\circ} \mathrm{N}$, but can be 


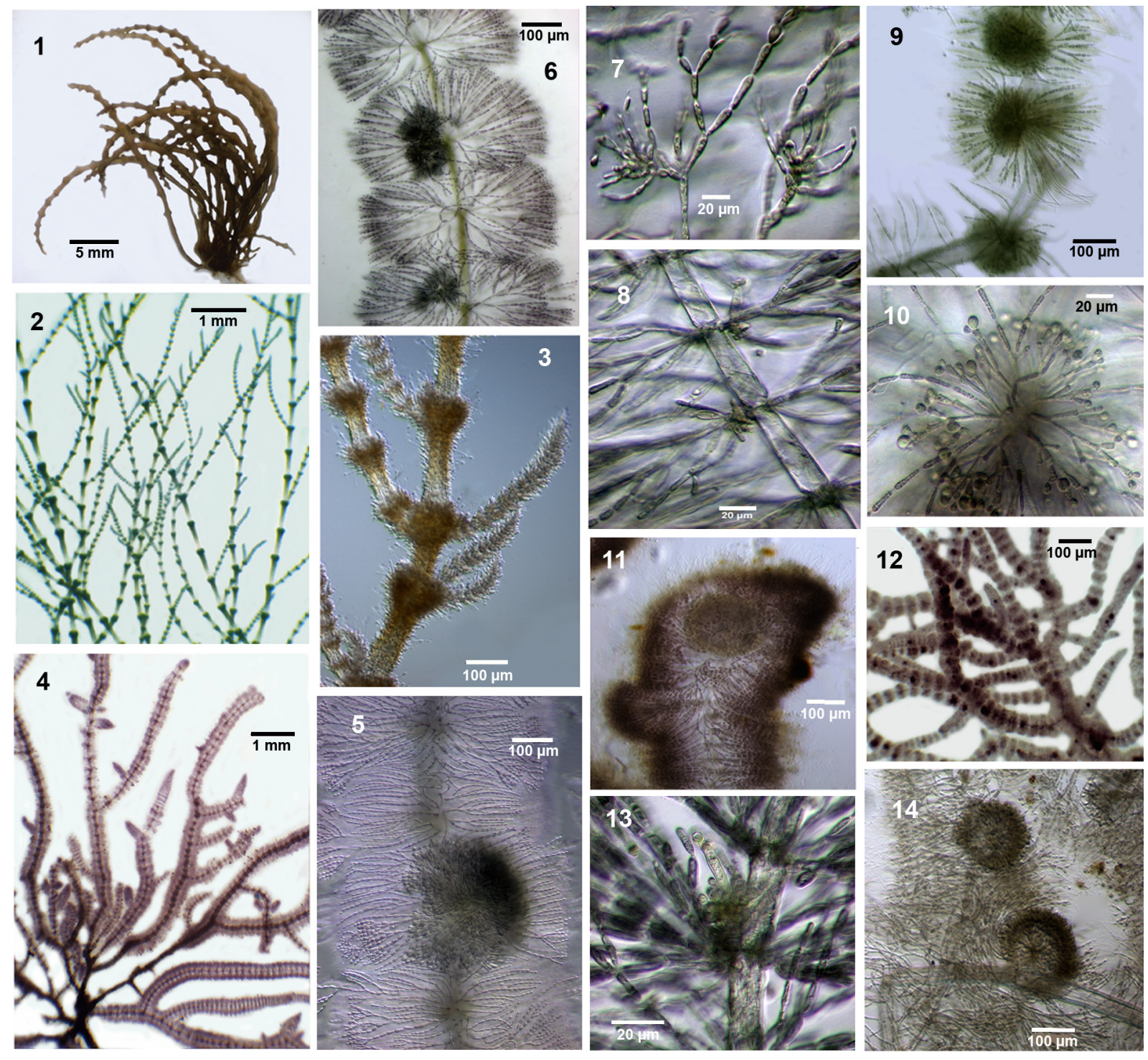

Fig. 9. Some rare red algal taxa found during the study: (1) Lemanea condensata, (2-3) Batrachospermum atrum, (4-5) Kumanoa virgatodecaisneana, (6-8) Batrachospermum elegans, (9-10) Kumanoa globospora, (11-14) Batrachospermum vogesiacum.

found in waters with somewhat increased conductivity. Chantransia group occurs, like in Sweden, in the whole country. Sirodotia group could be named as the most typical group for the northwestern part of the studied province with typically low conductivity, low $\mathrm{pH}$ and humic, brown waters. All of Lapland could be named as the area for the Condensata group. Although Finnish Lapland is not mountainous, the climatic and seasonal conditions are similar to western Sweden on Scandian mountain slopes. Israelson names Batrachospermum vogesiacum to Condensata group, but with comment that this species has very similar ecology to Sirodotia suecica. Thus, in the study area $B$. vogesiacum belongs to Sirodotia group.

ACKnowledgements

Our warmest thanks to students Stina Potoinen, Mira Latva and SELMA NÄRKKI for their careful help in the fieldwork in summers 2013 and 2014. Dr. habil. Janina Kwandrans-LeE helped many times during the years in the laboratory work and identification. The project was supported by the Centre for Economic Development, Transport and the Environment of Central Finland, the Ministry of the Environment, Finland and R. Erik Serlachius Foundation.

\section{REFERENCES}

Cedercreutz, C. (1929): Süsswasseralgen aus Petsamo. Memoranda Soc. Fauna Flora Fennica 5:140-158.

Cedercreutz, C. (1944): Einige für Finnland neue Süsswasseralgen. - Memoranda Soc. Fauna Flora Fennica 19: 84-87.

Eloranta, P. \& Kwandrans, J. (1996): Distribution and ecology of freshwater red algae (Rhodophyta) in some Finnish rivers. - Nordic J. Botany 16: 107-117.

Eloranta, P. \& Kwandrans, J. (2002): Notes on some interesting freshwater Rhodophyta from Finland. - Algological Studies 105: 95-109.

Eloranta, P. \& Kwandrans J. (2007): Freshwater red algae (Rhodophyta). Identification guide to European 
taxa, particularly to those in Finland. - Norrlinia, 15: $1-103$.

Eloranta, P.; Kwandrans, J. \& Kusel-Fetzman, E. (2011): Rhodophyta and Phaeophyceae. - Süsswasserflora von Mitteleuropa - Freshwater Flora of Central Europe 7. - 155 pp., Spektrum Akademischer Verlag, Heidelberg,

GRÖNBLAD, R. (1934): A short report of the freshwater-algae recorded from the neighbourhood of the Zoological Station at Tvärminne. - Memoranda Soc. Fauna Flora Fennica 10: 256-271.

HäYRÉN, E. (1945): Spridda anteckningar om alger och vattenvegetation i Finland. - Memoranda Soc. Fauna Flora Fennica 20: 4-10.

Israelson, G. (1942): The freshwater Florideae of Sweden. Symbolae bot. upsalienses 6 (1): 1-134.

John, D.M.; Whitton, B.A. \& Brook, A.J. (2002): The freshwater algal flora of the British Isles. An identification guide to freshwater and terrestrial algae. -702 pp., Cambridge University Press, Cambridge.

John, D.M.; WhitTon, B.A. \& Brook, A.J. (eds) (2011): The freshwater algal flora of the British Isles: An identification guide to freshwater and terrestrial algae. $-2^{\text {nd }}$ ed. -878 pp., Cambridge University Press, Cambridge.

KeIL, E.J.; Macy, T.R.; Kwandrans, J.; Eloranta, P.; Tomás, P.; ABoAL, M. \& VIS, M.L. (2015): Phylogeography of Batrachospermum gelatinosum (Batrachospermales, Rhodophyta) shows post-glacial expansion in Europe. -Phycologia 54: 176-182.

Knappe, J.; Geissler, U.; Gutowski, A. \& Friedrich, G. (1996): Rote Liste der limnischen Braunalgen ( $F u$ cophyceae) und Rotalgen (Rhodophyceae) Deutschlands. - Schr.-R. Vegetationskde. 28: 609-623.

Knappe, J. \& Huth, K. (2014): Rotalgen des Süßwassers in Deutschland und angrenzenden Gebieten. - Bibliotheca Phycologica 118: 1-142.

Kumano, S. (2002): Freshwater red algae of the World. - 375 pp., Biopress Ltd., Dorset.

Kusel-Fetzmann, E. (1986): Zur Gefährdung der Österreichischen Süsswasseralgen. - In: NicklfELd, H. (ed.): Rote Liste gefährdeter Pflanzen Österreichs. - Grüne Reihe des Bundesministeriums für Gesundheit und Umweltschutz 5: 194-209.

Kwandrans, J. \& Eloranta, P. (1994): Tuomeya americana a freshwater red alga new to Europe. - Algological Studies 74: 27-33

KWANDRANS, J. (2014): Różnorodność gatunkowa i rozmieszczenie geograficzne krasnorostów słodkowodnych (Rhodophyta) wybranych ekosystemów wodnych Polski oraz zróżnicowanie genetyczne w obrębie populacji europejskich. - Diversity of freshwater Rhodophyta of selected water ecosystems in Poland with molecular studies of the relationships within some European populations. - Raport końcowy z realizaczi grantu Nr N N304 285973.

KyLIN, H. (1912): Studien über die schwedischen Arten der Gattungen Batrachospermum Roth und Sirodotia nov. gen. - Nova Acta Regiae Soc. Sci. Upsal., ser. 4, 3 (3): $40 \mathrm{pp}$.

Lam, D.W.; Entwisle, T.J.; Eloranta, P.; Kwandrans, J. \& VIs, M.L. (2012): Circumscription of species in the genus Sirodotia (Batrachospermales, Rhodophyta) based on molecular and morphological data. - European Journal of Phycology 47: 42-50.
Luther, H. (1954): Über Krustenbewuchs an Steinen fliessender Gewässer, speziell in Südfinnland. - Acta Botanica Fennica 55: 1-61.

NeCCHI JR., O. (1990): Revision of the genus Batrachospermum Roth (Rhodophyta, Batrachospermales) in Brazil. - Bibliotheca Phycologica 84: 1-201.

Necchi JR., O.; Branco, C.C.Z. \& Branco, L.H.Z. (2000): Distribution of stream macroalgae in São Paulo State, southeastern Brazil. - Algological Studies 97: $43-57$.

Necchi Jr., O.; Lam D.W.; Agostinho D.C.; Kwandrans J.; Eloranta P. \& Vis M.L. (2013): Systematics of section Turfosa of the genus Batrachospermum (Batrachospermales, Rhodophyta). - Phycologia 52: 63-78.

NeCCHI JR., O. \& VIS, M.L. (2012): Monograph of the genus Kumanoa (Rhodophyta, Batrachospermales). - Bibliotheca Phycologica 116: 1-79.

Sheath, R.G. \& HambrooK, J.A. (1990): Freshwater ecology. - In: Cole K.M. \& Sheath, R.G. (eds): Biology of the red algae. - pp. 423-453, Cambridge University Press, New York.

Sheath, R.G. \& Sherwood, A.R. (2002): Phylum Rhodophyta (Red Algae). - In: JoHN D.M.; WhitTon B.A. \& BRooK, A.J. (eds): The freshwater algal flora of the British Isles. An identification guide to freshwater and terrestrial algae. - pp. 124-143, Cambridge University Press, Cambridge.

SiemińsKa J. (2006): Red list of the algae in Poland. - Czerwona lista glonów w Polsce. - In: MiReK, Z.; ZARZYCKI, K.; WojewOda, W. \& SzeląG, Z. (eds): Red list of plants and fungi in Poland - Czerwona lista roślin I grzybów Polski. W. Szafer Institute of Botany, Polish Academy of Sciences, Kraków. - pp. 35-52, Drukarnia Kolejowa Kraków, Kraków.

Skuja, H. (1933): Die Batrachospermaceen und Lemaneaceen Finnlands. - Memoranda Soc. Fauna Flora Fennica 9: 139-141.

Starmach, K. (1984): Red algae in the Kryniczanka stream. - Fragm. Flor. Geobot. 28: 257-293.

VIS, M.L. \& SHEATH, R.G. (1999): A molecular investigation of the systematic relationships of Sirodotia species (Batrachospermales, Rhodophyta) in North America. - Phycologia 38: 261-266.

(C) Czech Phycological Society (2016)

Received September 16, 2015

Accepted October 20, 2015 